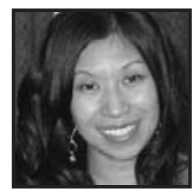

\title{
A Reflective Turn: Towards Composing a Curriculum of Lives
}

\author{
Simmee Chung, University of Alberta
}

\section{ABSTRACT (Press Here for Sound)}

This study is part of a larger inquiry (Clandinin \& Connelly, 2000), attended to children's, teachers', and parents' narratives of experience situated within institutional, cultural, and social narratives shaping particular school contexts. As one teacher engaged in an autobiographical narrative inquiry alongside her mother's lived and told stories, she learned curriculum making is intergenerational and woven with identity making. This teacher's narrative inquiry led her to new ways of knowing, reshaping her practice. The study illuminates the importance of attending to the interwoven, intergenerational stories of teachers, children and parents stories in cocomposing a curriculum of lives.

\section{Introduction: Slowly Awakening}

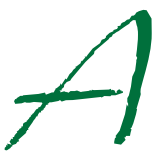

s I re-read the children's book, What You Know First, I closed the cover, firmly ending my thinking about it or so I thought. Only a few phrases adorned the pages of MacLachlan's (1995) book but somehow her words lingered. A child's story of leaving a known and loved place was all too familiar to me. While the words were scarce, the story was complex. I began to wonder about my life story and what it was that I knew first. And so I reflected on my first landscapes or what Greene (1995) might describe as my "rememory" (p. 82). Although Greene points out that, "We cannot return to the landscape of those pre-reflective days," she reminds me of the importance of reflecting on earlier landscapes for "We can only become present to them by reflecting on them" (1995, p. 73). Through reflecting and rewriting my storied 
landscapes, I invite new possibilities of being present and aware of stories not yet written in my "open-ended selves" in my process of becoming (p. 72).

At first, I found myself thinking "within" the frame as I often did, seeing my stories as fixed, already written, as if they were "once upon a time." Not until I began to attend to my stories and listen to others' stories "lived and told," ${ }^{1}$ that is, to engage in autobiographical narrative inquiry, did I begin to see beyond the borders that confined who I was and who I could become in my personal and professional landscapes. As I continued to inquire, I eventually attempted to write my life stories (Clandinin, Steeves, \& Chung, 2007) and awakened to understand that who I am, and am becoming, is not composed in isolation, nor is it fixed. My stories are both deeply interwoven, and can be re-told and re-lived, with those who live alongside me. Setterfield (2006) calls me to consider the complex interconnections of my life as interwoven with the lives of others. She writes,

Human lives are not pieces of string that can be separated out from a knot of others and laid out straight. Families are webs. Impossible to touch one part of it without seeing the rest vibrating. Impossible to understand one part without having the sense of the whole (p.59).

Setterfield's metaphor reminds me that my past, present and future stories are shaped by narratives "lived and told" of others in my life. My story does not begin or end with me, for my stories vibrate, touching others' lives, just as theirs touch mine. I can shift and rewrite my "stories to live by"2 (Connelly \& Clandinin, 1999, p. 4).

Greene (1995) recalls the shapes of her childhood as she describes the layers of complexity in life stories that shape and shift who each of us are, and can become. She writes,

I cannot truly say, "my life story." For that would imply that, spiderlike, I have somehow spun a web solely from the stuff of my own being. When, in fact, I cannot exclude the contexts of gender, sibling, and maternal relationships, political and professional phenomena, and even aging and decline from "myself." I am not so "individual" that I can claim to be free from the shaping influence of contexts ... (1995, p. 74). 


\section{Coming to the Research Puzzle}

My narrative puzzle started when I began graduate studies at the University of Alberta in 2004. Not knowing what to expect, I decided to take a course titled, Life in the Elementary Classroom taught by Jean Clandinin and Pam Steeves. The safe space created in this course and the openings to look inward and outward, backward and forward, helped me unfold a narrative life puzzle that continues to be composed and re-composed. As I attended more closely to stories lived and told of my personal and professional landscapes, I slowly began to write and re-write my autobiographical narratives (Clandinin, Steeves, \& Chung, 2007).

As part of my narrative inquiry, I was encouraged to bring in memory items from my lived stories. The first artifact I brought was a photograph of my mother and me in front of our Fish and Chip shop. At the time, I was not certain why I chose to share this picture, but somehow I was drawn to it, compelled to speak to it.

With two colleagues in my "Works in Progress," 3 I shared fragments of growing up in England. I began with telling cheerful anecdotes that implied my story was a fixed entity, already written. I all but stated, "The end." At the time, I did not realize I was just beginning my narrative inquiry. As we listened and responded to each other's stories, trust between members of my Works in Progress group grew. They asked me more questions and I began to awaken to the cover stories and the secret stories I told. Connelly and Clandinin (1995) describe cover and secret stories as narratives composed to help an individual portray and uphold more acceptable images of one's life in order to fit into the dominant school culture. These "masked" stories are told to others both on and off the school landscapes (p.61).

Inquiring more deeply into the stories that lived outside the temporal, social and emotional edges of this photograph, the safe cover story I had shared slowly began to unravel. As I awakened to the layers of the stories, I felt a tension that momentarily dispositioned ${ }^{4}$ me. As I thought about the unraveling of the stories, resonating were my teachers' words, "Attend to the edges, examine the gaps ... the silences." In learning to look beyond the edges of this photograph, I uncovered multiple plotlines to the stories I was telling. There was a more complex story being lived as my mother and I negotiated our "living curriculum" whilst living out our "curriculum as planned" (Clandinin et al., 2006). The happy anecdote I first told about the photograph was incomplete, resisting framing as our "curriculum of lives," 5 was being co-composed on a multiplicity of landscapes. This "once upon a time" story was not enough. I began to tell and retell my stories and my mother's stories through narrative inquiry (Clandinin \& Connelly, 2000). Greene noted, "No one of us can see the 
whole or sing the whole." Greene reminds me that "no one's picture is complete" (Greene as cited in Miller, 1998, p. 145). In coming to know the necessary "incompleteness" of my mother's and my stories to live by, my narrative inquiry puzzle began.

The stories I share in this paper are rememories of earlier landscapes with my family. Although the narrative accounts are written from my vantage point, they were composed through conversations over time with my mother. My mother's telling of her lived experiences provided me insight into her vantage point.Therefore, in collaboration with my mother, I wrote family stories grounded in both of our rememories and retellings. As we retell and relive our stories, our family stories continue to vibrate onward, touching the stories we now live. Necessarily, these vibrations linger, reverberating into who I am and can become as a teacher as I live alongside young children.

In this paper, I also share a story of a child I lived alongside. I retell the story of this child in order to show how thinking narratively allowed me to "know" and "unknow" my students in new ways (Vinz, 1997). As I attend closely to the vibrations from my past, I begin to understand that, even as adults, vibrations in our webs of life, linger ...

\section{Vibrating Stories}

\section{First Landscapes: The Fish and Chip Shop}

My family and I experienced many transitions over the years. We moved from England to Fort Saskatchewan, to Wainwright and then to a little town called Edgerton. As I looked through old photographs, I was drawn to a photograph of my mother tightly holding my hand. In the background was our small Fish and Chip shop in England. Clinging tightly to my mother, I looked like a timid little girl.

I do not recall much of England as I was so young, but I do hold onto the rememories my family tells of it. My mother and my siblings tell me I cried often at pre-school. Sometimes my sister was asked by the principal to keep me company. I wonder why I do not remember that. I do recall a fire in our Fish and Chip shop. I cried as we watched it from inside the car. I was certain the fire was an inferno but, when my mother tells this story, she describes it as a small kitchen fire.I remember the enormous slugs that blanketed the sidewalks whenever it rained and it rained often. Terrified to squish them with my feet, I asked my parents to lift me up. Looking back at who I was in that photograph, I see a little girl who was afraid of many things. 
My mother also describes a moment of tension when she thought she almost lost me. Distracted, as she was tending to a friend's child, I wandered onto the busy road in front of the shop. My mother grabbed me off the curb just before the oncoming traffic went by. I wonder if, from that point on, my mother felt a need to keep a watchful eye on me. She proudly reminds me that when I was a baby, while she worked, she carried me on her back.

\section{Earlier Landscapes: Leaving What I Knew First}

My siblings and I spent most of our time at the Fish and Chip shop. It was only fitting that we celebrated our birthdays there. After all, it was home, or so it seemed to me. Not long after my fourth birthday, my parents announced we were moving to Canada. I was sad to leave what I knew first as my homeplace. I did not understand why we would leave a place we loved.

My father, brother, sister and I moved to Canada first while my mother stayed behind to sell the Fish and Chip shop. With no home of our own, we lived in the basement of my uncle and his family's home. A new place, so many unknowns, I was scared without my mother by our side. During my mother's absence, my father tried his best. He bandaged our wounds, comforted us, and even styled our hair or at least attempted to. Eventually, I had to start kindergarten, another unknown. With so many transitions, I grew more fearful. My dad had to work so my aunt took me to my first day of school. Carrying me in her arms, my aunt tried to hand me over to the teacher. Refusing to go, I kicked the teacher squarely in her shin. There were many tears to follow that day as I stood on my own with no one to carry me. However, still carrying me with her words, I sought comfort in speaking to my mother every day over the telephone until she eventually joined us in Canada.

\section{Blurring of Past and Present Landscapes: Bean Sprouts Do Matter}

We came to meet and leave many "homeplaces." Eventually we moved from my uncle's home to new places as my parents went wherever opportunity took them. Now my parents live in a trailer nestled beside their restaurant in a small village in Saskatchewan. I moved to Edmonton for postsecondary education and have stayed ever since.

I recall one cold day when I visited. My mom sighed as she told how the pipes froze again and the dishwasher was broken. Awakening early one morning to help my mother open the restaurant, I noticed she was daydreaming. As if in a half 
sleep, her tacit knowledge artfully guided her in cutting vegetables for the daily soup special. Gazing at my mother, I wondered if these seven days a week, 7 a.m. to 11 p.m. workdays, was the life she had imagined for herself.

As I served local patrons who have become more like family than customers to my mother and father, they said to me, "Ah ... so you're the school teacher. Your mother is so proud of you. She talks about you." I smile and remember how my mother once had hoped I would take over the family business. I pursued my dream whereas she chose a life to give her family opportunity.

In another visit, I remembering helping my mother prepare our evening dinner at 10:00, after the restaurant finally closed. Placing a large bowl full of bean sprouts in front of her, my mother began carefully tearing off the top of the sprout and the tip, leaving only the stem. I grabbed a few bean sprouts and began imitating my mother's actions. After painstakingly tearing only a handful of stems, I wondered why my mother took such time and care to do what seemed like such a trivial task. Impatient and tired, I asked my mother, "Why can't we just eat the bean sprouts the way they are?" As my mother leaned over to redo some of my carelessly torn bean sprouts, she shared a story that made me realize that there was a purpose and story to everything my mother does, no matter how small or big it might seem. Not looking directly at me, my mother asked if I knew what my grandmother did for a living. I was eager to hear more as my mother always spoke so lovingly of her mother who passed away from cancer many years ago. I could tell my mother was proud as she described how my grandmother used to work in different five-star restaurants in Hong Kong. Always holding at least two jobs, my grandmother's job was to peel shrimp as well as to tear off bean sprout tips. My mother's eyes watered as she told the story of my grandmother who raised four children while holding down multiple jobs. As I listened, I began to understand why she took such care in tearing those bean sprouts for it reminded her of her mother. Awakened to new stories of my mother, her mother, that night, in silent appreciation, I continued to tear bean sprouts with my mother until the entire bowl was finished.

\section{Treasured Landscapes: Tattered "Little Sister"}

During my usual spring "clean sweep," I rummaged through my closet to find items to donate to a local charity. I gathered three bagfuls of clothes and, eventually, a bag of stuffed animals, most of them gifts. Each stuffed animal was a memory trigger of a time, person, or place; there was one in particular that I loved: my childhood teddy bear from England. As a child, I affectionately named my bear in Chinese, 
calling it "little sister." Tattered, with yellow stuffing coming out of its belly, my bear was clearly well loved. This last keepsake, my ragged teddy bear, recalled, for me, the security I felt being with my family in England. I knew it was my favourite childhood toy as I had seen countless photographs of me hugging it tightly as a little girl. As part of the clean sweep, I decided to let go of my childhood love. An adult surely did not need childhood mementos. Putting my precious bear in the bag, I was certain it would be the last time I would see it.

I meant to bring the bags to the charity but they ended up collecting dust in the basement, that is, until my mother visited. Seeing the bags labeled "Donations," she asked if she could give the items to families in need in the small town where she lived. In her usual way, she was tending to people in the community. My mother took the bags when she left.

Several months later, I looked up on my closet shelf where "little sister" used to sit and I found myself missing my English bear. As I recalled fond memories of our life together, a realization struck me. Who on earth would want my tattered teddy bear but me? I could not believe I had given away my childhood treasure which reminded me of a place I loved.

I was a bit frantic as I could not remember what I had done with the donation bags. I was certain my bear was gone for good until the day my mother called. With exasperation in her voice, she first gave me a lecture on how I was wasteful, throwing out perfectly good things. Then she told me she had found my "little sister" bear among the clothes she took from my basement. She had stitched up my bear's ripped belly because she thought I might like to keep it. On my mother's visit, she handed me my bear. It was what Lugones (1987) would call my mother's "loving perception" of knowing what the bear meant to me, and, perhaps, her way of reminding me of who I was and where I came from. When my mother gave me my bear, I hung tightly to it and to her every word as she told me more stories of England. When I was a toddler, she used to bring me to the fish market at six in the morning in order to get the best produce for our shop. I laughed as my mother described how I would cry whenever we forgot to bring my "Little Sister" to the market, which was apparently quite often. Even if we had almost reached the market, my mother and I turned back to get my bear. I think my bear meant as much to her as it did to me for it brought us back to our special times together in England. Undoubtedly, my mother wanted me to remember this. 


\section{Reliving, Retelling ... in the Margins}

At the age of eight, I was in grade three in my third school. Being a shy student, I hardly ever spoke in class. However, my family tells me that, to their dismay, I had no shortage of words at home. Although shy in school, I attempted to respond whenever the teacher spoke to me. Unfortunately, my soft voice was often barely audible. I remember dreading my turn to read as our teacher went up and down the rows beckoning us to read aloud.

Grade three was full of new knowings and unknowings: I had my first crush on a boy; learned the multiplication table; wrote my first standardized achievement tests. Being Chinese, I was the only visible minority in my class. There were not many Chinese people in the school except for my brother, sister and me. I wanted desperately to fit in and be like other children. I was thankful I was losing traces of my British accent which had not helped me fit in. I did not realize that grade three would also be the year I was labeled a struggling ESL student. I do not recall exactly how I came to earn this "special" label, but I do remember the feeling I had when I first became aware I was labeled as an ESL student and a struggling learner. I was not even aware that English was my second language for it had become the language I was most comfortable with as I lost my grasp of the Chinese dialect.

Many times I was pulled out of class that year for remedial English. I had to go to a small room at the end of the hallway with what seemed like an enlarged door sign noting "Learning Assistance." As I half-heartedly completed isolated vocabulary exercises and simple board games, I wondered what was wrong with me. Why was I the last to know I was a struggling learner? I wondered if I should stop reading the novels I loved so much. In 'Learning Assistance' I frequently earned prizes and even a ribbon once for my apparently exceptional efforts. These prizes did not deter me from wanting to scream and shout, "I am not dumb!" every time I was pulled for remedial instruction. Instead, I said nothing. I stayed silent. I wondered if my school friends thought I was dumb too, for I was the only student who always pulled out of class.

From an early age, I took solace in books and music. A vigorous reader, I found myself immersed in literature where I could imagine my life as otherwise, that is, a life where I was a "smart" student. The day I was given a series of standardized tests, the remedial instruction abruptly stopped. I did not know why it ended but I was elated. Was I cured of my dumbness? Strangely, I did not recall feeling smarter. I wondered if the board games had done wonders after all. I did not dare question why remedial instruction ended for I grew apprehensive, fearing the teacher might change her mind and send me back. As I progressed through grade school, I was 
relieved not to be singled out for my deficits, only for successes and accolades. However, the memories and labels I carried in grade three unknowingly lingered as I grew fiercely determined to show my family, friends, and teachers that I was, indeed, a good student, a smart student.

In grade eleven, I transitioned to another school. After a year in my new school, one day, unexpectedly, the jovial high school principal summoned me over the intercom to his office. I was surprised as I was now known as a "good" student. Going to the principal's office was uncharted territory for me. To my relief, my principal only wanted to know if I wished to review my educational history. As we looked over my profile, he wondered why, in grade one, my report card noted that I liked to stay in at recess and read by myself. My principal found this particularly amusing as he saw me as an outgoing student. Then he marveled how in grade three my reading score in an achievement test was recorded to be three years above grade level. Being the first time I heard this news, I was rather shocked myself for it was the same year I carried my insignia, as the dumb student.

I did not know how my memories of this early landscape would linger with me as I continually questioned who I was. Was I an ESL student? Was I a good, smart student? Was I still dumb? After nine years and having experienced continued academic success after grade three, I still wondered about the assumptions placed on me as a child. Even as an adult, in my graduate classes, I had silenced this story but it was through this self-facing narrative inquiry that I began to ask myself,"Why?" I wondered how these stories of coming to know myself and who I was vibrated into my teaching.

\section{Vibrating Into the Classroom: A Right-Sided Heart}

As his mother picked him up to go see the doctor, Vlad ${ }^{6}$, a child in my classroom, made a point of coughing forcefully. Eventually all of his classmates noticed him. They turned around in their desks to look while one asked, "Vlad are you sick again?" In a weary voice, he replied, "Yeah ... as usual" (field notes, October 19, 2006). I remember when I first met Vlad. I thought he was in contention for an Oscar with his frequent theatrical outbursts. Early in the year Vlad had an angry rage over an accidental brush with a classmate during gym class. It took almost an entire afternoon to calm him. Shortly afterwards, Vlad complained about a pain in his chest. "My heart hurts," he said as he put his hand over the right side of his chest."Is my heart here?" he questioned. I gently told him that I thought his heart was on the left side. He was adamant he could feel his heart on both sides (field notes, October 4, 2006). "What an 
actor!" I initially thought. As I thought more about Vlad, I began to wonder about who he was. In that moment, I awakened to how I would come to unknow Vlad; beginning with this unknowing, enabled me to know him. I thought I knew this nine-year-old boy of Bangladeshi and Anglo heritage. Was he not an extremely high achiever and a fierce competitor? I had many labels for how I knew him but I realized that none of these imposed identities helped me know the whole of him.

During a mathematics test I began to know the layers of complexity in Vlad's life stories. A high achiever, Vlad, a seemingly tough boy who showed little affection to me or his peers, began his test with what seemed like his usual intent of getting $100 \%$. However, during the test, I noticed Vlad uncharacteristically losing focus. Eventually, Vlad put down his pencil and requested a private conversation with me. His voice quavered as he asked, "Ms. Chung, are people allowed to copy movies?" I asked Vlad why he was worried about this. He shared his worries about the repercussions of what might happen to his father who copied movies. He loved his father and treasured the time he had with him as Vlad traveled back and forth between his mother's house during the week and his father's house on the weekends. I listened to Vlad tell his life story. Afterwards, still worried, Vlad wanted to finish his test. Wiping away his tears, in his usual quest for perfection, Vlad told me of his expectations to get all "A's" on his report card. He prided himself on being seen as a "smart" student. When he completed his test, I was surprised when Vlad, such a private boy, wanted to continue our conversation.

I marveled about how much I learned about who Vlad was on that singular day. That day I let go of my assumptions, my labels. I became a "world traveler" (Lugones, 1987) as I saw the parallels between our stories. Vlad, too, defined himself by his achievements. He, too, was trying to make sense of his dual world, living in between two cultures. I thought about the assumptions and labels I unknowingly placed on him, ones similar to those stamped on me as a child. There was so much more about this little boy I needed to know. As we continued our journey of unknowing and knowing ourselves together, more stories came forth. Vlad was an important thread in my life. As Vlad felt safe to share more of his stories, not only with me but his classmates, we all began to know him in beautiful ways. Vlad passionately shared with us his dream of being a researcher who would find a cure for cancer and diabetes (field notes, June 6, 2007). Through listening to his lived stories and those still yet to live out, I knew there would be complex layers to knowing the depths of who Vlad was and who he would become. As his teacher, it was not my position to determine and write out his life script for him. My important role was to listen and to embrace stories of his open-ended self in his personal journey of becoming. 


\section{In-Between Spaces: Retelling the Stories}

\section{Beginning With a "Master" Story}

Much like Aoki (1993) described in his own self-facing as a teacher, l, too, began my first year of teaching with "curriculum guides woven into a master story" (p. 264). As a character in this "master" story that was already written, I merely enacted the script, carrying out the "curriculum-as-planned" (Aoki, p. 264). I made sure I taught the curriculum objectives as outlined by policy makers. I consulted with my daily planning book that kept me "on task" and "on schedule." Yet, I felt there was always something that happened in the ongoing life in the classroom that disrupted my rhythm. These "things" were life stories that I did not know how or where to fit into the already brimming mandated curriculum.

By engaging in narrative inquiry, I began to ask myself questions about the place of subject matter in composing a curriculum of lives. Does the subject matter of mathematics, sciences, language arts, and other curricular subjects have any relevance at all in composing a curriculum if we do not attend to lives, the lives of the children, parents and me, as starting points and move from lives to subject matter (Clandinin, Steeves, \& Chung, 2007)?

\section{Letting Go of the "Master" Story}

This study helped me understand that what I initially thought was taking me "off course" was the "other" curriculum, the "lived curriculum." Aoki speaks of this lived curriculum as one that is not laid out in a plan but a plan more or less lived out (1993, p. 257). I have come to know, the most important curriculum of all cannot be scripted, pre-meditated or mandated. Our interwoven stories, those told, lived and yet to live, need time and space to be and "inter-be" (Nhat, 2003). As I work to co-compose the classroom curriculum making alongside the children, our narratives live at the forefront. What I once thought to be "disruptions" to the curriculum, I know now, to be the core. Stories are the rhythms in our classrooms; they give life to our curriculum.

It is through narrative engagement that I can now be on course as I move forward, seeing "big" as well as seeing "small," (Greene, 1995) rather than being confined to my previously recycled, unchallenged "cul-de-sac" ways of thinking and attending as I held on to my preconceived notions and labels as ways of seeing curriculum in schools, the world and others (Clandinin, Steeves, \& Chung, 2007). In an achievement testing era of increased accountability, Greene (1995) reminds me of the importance of not losing sight of seeing "big." She writes, "When applied to 
schooling, the vision that sees things big brings us in close contact with details and with particularities that cannot be reduced to statistics or even to the measurable" (p. $10)$.

In coming to know more of what has shaped my childhood and who I have become, my curiosity stays with me as I wonder about the webs of lives vibrating in the classroom. As we make safe spaces for children to share stories of who they are with one another, I wonder if the children know where they came from and what they knew first. I wonder how their stories will vibrate onward, influencing each other's stories still yet to be written. I wonder what the children know and will come to know of each other. I have come to understand that identity making is interwoven with curriculum making as subject matters will have no authenticity if we do not begin with what we know first. Who we are and our unfolding open-ended selves, our stories, do matter ...

\section{Staying Awake: Living in Possibilities}

I live in the stories of who I am and who I am not. Am I determined through my discourse to be an immigrant child, a struggling ESL student, a good student, or a high achiever? Through inquiring into my narrative puzzle, I came to know that these labels could never encapsulate all that I am and all that I am not. My stories are fluid and ever changing as they move with me through diverse landscapes. To understand who I am in any narrative sense as an individual, as an educator, I must understand the threads of my interwoven, intergenerational stories. The social, institutional and cultural narratives that shape my personal and professional landscapes influence who I am and how I teach.

I am a little girl who treasured memories of many homeplaces, places I had grown to love. I am a daughter who understands the loving perception that my mother has unknowingly taught me. I am an educator who works to dispel assumptions and labels. I have come to learn that bean sprouts do matter. I understand that it is possible to feel our hearts on both sides of our chest. I work to honour my students' living curricula by giving them the time and space to write their own stories. I am able to listen to their stories and "add a dab of glue to the important words that burst forth" (Paley, 1986, p. 121). By attending to the interwoven vibrations in my life stories, my family's stories and my students' stories, I am a "world traveler" in the way Lugones (1987) means as she reminds me of my capacity to remember other worlds and to see myself in them. I am able to imagine the world through my students' eyes. I can say, "I've been there too. I live alongside of you." 
Although I was deeply humbled to have recently received a teaching award, I know that labels and accolades do not define who I was, who I am or who I will become. My life stories are shaped and continue to be shaped by stories of those I am so fortunate to have live alongside of me. My mother reminds me of this when she wrote me this letter attached to a congratulatory card.

\begin{abstract}
Simmee,
Congratulations you are one of ton good teacher. Mom's English is very poor, but still try my best to write, hope you understand what I mean. All my family is so happy and hoping you keep going and do better and better. O.K. sweet heart. Now I send you some lucky money you can go out have a big meal ok. I will see you soon. Enjoy yourself Honey. I love you so much. Congratulation again.
\end{abstract}

Dad \& Mom \& Family (letter, April 25, 2008)

This was the first letter my mother had ever written to me. It was also the first time she wrote more than a sentence in English. I hung onto my mother's loving words as I knew every word was carefully thought out, just so. I know this letter will not be the last, for my mother and I will keep writing new stories-together. Numbered birthday cakes, a tattered teddy bear, a community garden, a singular fading flower, and tensions in our hearts-these are not things at all. These are our stories that give our lives rhythm.

On my most recent visit with my mother, she handed me a bagful of old congratulatory cards from my high school graduation. She told me she held onto them as she thought I might like to have them as keepsakes. At first I was inclined to quickly toss the cards and to begin my rant to my mother regarding her packrat behavior, but then I stopped myself. I stayed awake to knowing that these were not just cards. These cards reminded me of earlier stories, new possibilities to imagine, representing the intricate webs in my life. I find myself weaving MacLachlan's (1995) words into my new ways of knowing, "What you know first stays with you ..." but just in case I forget, I know the threads in my life will remind me to not take our stories for granted. My mother and my interwoven stories remind me of where I came from. I understand that what I know first is a part of me, but not the whole of me. My identity, my stories to live by, are multiple. Greene reminds me that, "Neither myself nor my narrative can have, therefore, a single strand. I stand at the crossing point of too many social and cultural forces; and, in any case, I am forever on the way" $(1995$, p. 1). 
As I sat in an overflowing room filled with other world travelers at the American Educational Research Association's (AERA) 2008 conference in New York City, we had the privilege of wondering alongside Greene who recently celebrated ninety years of living with possibilities. Speaking ever so eloquently, Maxine Greene's words wrapped around me, "I am what I am not yet ..." Awakened, I know that I am not closing this narrative with these words, I am only beginning. As I imagine and reimagine the open-ended spaces in my life, I am present to who I am and I live in the possibilities of who I am, not yet ...

\section{Notes}

1. Connelly and Clandinin (1999) see teachers trying to develop a coherent narrative account of themselves in the living and telling of their stories.

2. Connelly and Clandinin's (1999) notion of "stories to live by" refers to a narrative conception of identity, an understanding in which our stories to live by are shaped by secret stories, sacred stories, and cover stories. Our stories to live by are fluid, multiple, and shifting stories, composed and recomposed as they are shaped by the past and present landscapes in which a teacher lives and works. Stories to live by link the concept of teachers' personal practical knowledge and the professional knowledge landscape.

3. Works in Progress groups are small story groups that remain constant throughout the course in order to enable sustained conversations through listening and responding to each other's stories and writing.

4. I borrowed this term from Vinz (1997) who suggests the practice of "shifting valances of dispositioning" (p. 145) in which educators move between "unknowing," giving up present understandings (positions) of our teaching to "not-knowing; to acknowledge ambiguity and uncertainty" (p. 139).

5. Clandinin and Connelly (1992) conceptualize curriculum as a course of life, or as a "curriculum of lives." (p. 392).

6. Vlad is a pseudonym used to protect the privacy of this participant and to ensure anonymity. 


\section{References}

Aoki, T. (1993). Legitimating lived curriculum: Towards a curricular landscape of multiplicity. Journal of Curriculum and Supervision, 8(3), 255-268.

Clandinin, D. J., \& Connelly, F. M. (1992). Teacher as curriculum maker. In P. Jackson (Ed.), Handbook of research on curriculum, pp. 363-401). Toronto: Macmillan.

Clandinin, D.J., \& Connelly, F. M. (1998). Asking questions about telling stories. In C. Kridel (Ed.), Writing educational biography: Explorations in qualitative research. New York: Garland Publishing, Inc. (pp. 245-253).

Clandinin, D. J., \& Connelly, F. M. (2000). Narrative inquiry: Experience and story in qualitative research. San Francisco: Jossey-Bass.

Clandinin, D. J., Huber, J., Huber, M., Murphy, S., Murray Orr, A., Pearce, M., \& Steeves, P. (2006). Composing diverse identities: Narrative inquiries into the interwoven lives of children and teachers. New York: Routledge.

Clandinin, D.J., Steeves, P., \& Chung, S. (2007). Creating narrative inquiry spaces in teacher education. In Johnston, B. \& Walls, $\mathrm{K}$. (Eds). Voices and Vision in Language Teacher Education; Selected Papers from the Fourth International Conference on Language Teacher Education (CARLA Working Paper Series), 17-33. Minneapolis: University of Minnesota, The Center for Advanced Research on Language Acquisition.

Connelly, F. M., \& Clandinin, D. J. (1988). Teachers as curriculum planners: Narratives of experience. New York: Teachers College Press.

Connelly, F.M., \& Clandinin, D. J. (1995). Teachers' professional knowledge landscapes. New York:Teacher College Press.

Connelly, F. M., \& Clandinin, D. J. (1999). Shaping a professional identity: Stories of educational practice. New York: Teachers College Press.
Connelly, F. M., \& Clandinin, D. J. (2006). Narrative inquiry. In J. Green, G. Camilli \& P. Elmore (Eds.), Handbook of complementary methods in education research (pp. 375-385). Mahwah, NJ: Lawrence Erlbaum.

Greene, M. (1993). Diversity and inclusion: Toward a curriculum for human beings. Teachers College Record, 95(2): 211-221.

Greene, M. (1995). Releasing the imagination: Essays on education, the arts, and social change (1st ed.). San Francisco: JosseyBass Publishers.

Greene, M. (2008, March). From bare facts to intellectual possibility: The leap of imagination: A conversation with Maxine Greene. Paper presented at the American Educational Research Association Annual Meeting, New York.

Lugones, M. (1987). Playfulness, "World"-travelling, and loving perception. Hypatia, 2(2): 3-37.

MacLachlan, P., \& Moser, B. (Illustrator) (1995). What you know first. Canada: Joanna Cotler Books.

Miller, J. (1998). Autobiography and the Necessary Incompleteness of Teachers' Stories. In W. Ayers \& J. Miller (Eds.), A light in dark times: Maxine Greene and the unfinished conversation. New York: Teachers College Press. (pp. 145-154).

Nhat, T. H. (2003). Creating true peace: Ending violence in yourself, your family, your communi$t y$, and the world. Toronto: Free Press. (Chapter 3: Peace Begins with Us: Taking Your Practice into the World, pp. 54-75).

Paley, V. (1986). On listening to what the children say. Harvard Educational Review, 56, 121-131. Setterfield, D. (2006). The thirteenth tale. Canada: Bond Street Books.

Vinz, R. (1997). Capturing a moving form: Becoming as teachers. English Education, 29(2), 137-146. 


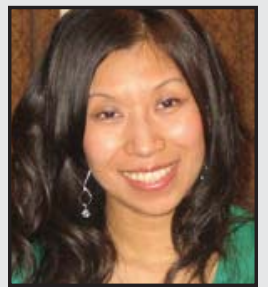

Simmee Chung, a graduate student at the University of Alberta, is a recipient of Alberta's Provincial 2008 Excellence in Teaching Award. Her co-publications with Jean Clandinin and fellow scholars focus on narrative matters in teacher education and conceptualizations of student engagement. Her masters thesis is a narrative inquiry into the interwoven, intergenerational stories of teachers, children, and families as they work towards co-composing a curriculum of lives in schools.

LINK TO:

http://www.uofaweb.ualberta.ca/elementaryed/CRTED.cfm 